\title{
A FEMINIST LOOK AT THE DEATH PENALTY
}

\author{
AMY E. POPE * \\ INTRODUCTION
}

The death penalty has its fervent defenders and critics. In all the debate about the procedure, however, no one has suggested how a feminist perspective might improve the discussion. Feminist theory can be helpful in several ways. First, we can learn from the lives of the women embroiled in the process. Indeed, fifty-four women currently live on death row. ${ }^{1}$ Not only are women themselves imprisoned by the state, but women are also the mothers, sisters, and wives of those condemned to die. Countless numbers of women are the victims of the crimes for which men are sentenced to death. And women are, in still small but growing numbers, the judges, prosecutors, and defense attorneys embroiled in the process. Second, and more importantly, the decision to impose the death penalty and the procedures for doing so present traditionally male ways of looking at the problem, presenting judges and juries with a limited means of considering the issues: Universal standards are divorced from context, dichotomous choices are imposed in place of a range of alternatives, and emotions are excised from the procedure. Imposing a feminist lens on the procedure will round out the largely one-sided argument.

For these reasons and others, it is appropriate to look at the death penalty from a feminist perspective. How has the system affected the lives of women? How does the process and the punishment reflect the voices of women? Why are so few women sentenced with this penalty, and what does this imply about our culture? What is the feminist response to a procedure that ostensibly rids this country of the people who threaten women in the most violent ways?

In Autumn 1998, Law and Contemporary Problems published an issue exploring the American Bar Association's Proposed Moratorium on the Death Penalty. ${ }^{2}$ This note advances another argument in favor of the proposed moratorium - that, by employing feminist methodology to examine the death pen-

Copyright (C) 2002 by Amy E. Pope

This note is also available at http://www.law.duke.edu/journals/65LCPPope.

* J.D. 2001, Duke University School of Law.

1. Death Penalty Information Center, http://www.deathpenaltyinfo.org/womenstats.html (last updated July 1, 2001). This number represents only two percent of the more than 3,600 men currently living on death row.

2. See Symposium, The ABA's Proposed Moratorium on the Death Penalty, 61 LAW \& CONTEMP. PROBS. 1 (Autumn 1998). 
alty, it becomes clear that the current procedural system fails to represent large numbers of those penalized under the system. Accordingly, the major purpose of this note is to start a conversation about the ways in which thinking from a feminist perspective may help us, as a society, to approach the death penalty in a more productive and holistic fashion. This note points out that, even when there is a horrible crime, and instinct calls for death, there are contextual factors that must be considered. Universal standards that require "yes" or "no" answers fail to address the needs of both the victims of crime and its perpetrators. Until criminal procedure is reconfigured to better represent those voices, it is inappropriate for the democratic state to impose such a final and severe sentence.

After a brief exploration of the need for a feminist perspective on capital punishment in Part II, Part III begins by determining which feminist methodology is most appropriate to an analysis of the death penalty. The strengths and weaknesses of two of the many models of feminist thought are specifically outlined. I do not attempt to defend the wisdom of one school of thought over the other; rather, my goal is to fuse the two theories to create a different way of looking at the capital punishment system. Part IV applies this hybrid methodology to the leading Supreme Court cases on the death penalty and asks whether we should have the death penalty at all. The note then considers, if we are to have the death penalty, how we might make the procedure more fair. Part V questions the procedures used to employ capital punishment and finds discrepancies in how the law handles cases involving crimes committed in the public and private sphere. Part VI considers victim impact statements as an example of an attempt to universalize the criminal justice system, and considers how the initiative has fallen short. The note concludes by suggesting that, while there is no immediate resolution to the problem, rethinking capital punishment from a feminist perspective will start a more productive discussion of the issue.

II

\section{Why We Need A Feminist Perspective on the Death Penalty}

Since the earliest of times, and certainly within the history of the United States, the voices of women have been absent from the criminal justice system. White men of property wrote the Constitution. The laws of the federal government and of the states overwhelmingly have been drafted and executed by men. Even today, only thirteen women are United States Senators, and sixtyone women are members of the House of Representatives-far from proportionate to the number of women in this country. ${ }^{3}$ Similarly, women have yet to receive equal representation on the bench where the law is interpreted. ${ }^{4}$

3. See http://www.4woman.gov/nwhic/current/107th\%20congress.htm; see also http://www.gender gap.com/government/governor.htm (noting that record high was set in January 2001, when ten percent of all U.S. governors were women).

4. See http://www.gendergap.com/governme.htm (last modified June 6, 2001) ("One hundred and thirteen individuals have been appointed to the U.S. Supreme Court . . . two are women. Excluding the 
Despite the scarcity of women's voices in the creation of the criminal justice system, women are hardly missing from the equation. Omnipresent throughout criminal legislation is the notion that laws can be used, through the know-how of men, to protect and preserve the sanctity of "womanhood." The central premise to this phenomenon, that the law is the protector of feminine virtue, legitimizes male dominance over women and was reinforced through ecclesiastical and legal traditions in the times even before our own laws were written. ${ }^{5}$ Even Aristotle, the "giant of Western thought," writing in the third century B.C., argued that it was the different natures of men and women that accounted for their disparate roles in society. In Aristotle's own words, "nature," not culture, men, or social forces, "has made the one sex stronger, the other weaker, that the latter through fear may be more cautious, while the former by its courage is better able to ward off attacks; and that the one may acquire possessions outside the house, the other preserve within."

Through the years, this social order, originally founded on disparities in physical strength, emerged as worthy of preservation through the law.' Laws sanctioned male pursuit of positions of public power, while largely ignoring women who, until quite recently, were confined to maintaining the home. Accordingly, the law developed by regulating interactions in the public sphere, leaving the home to private regulation. ${ }^{10}$ For this reason, until the midnineteenth century, there was little sympathy for granting women the right to

Supreme Court there are 1,612 Federal judges, 332 (20.6\%) are women, up from 154 (9.5\%) in 1997... Between 1980 and 1991, the percentage of women state judges increased from $4 \%$ to $9 \%$.).

5. See, e.g., Ephesians 5:22-24 (exhorting wives to submit to their husbands, as the husband is the head of the wife).

6. Renford Bambrough, Introduction to ThE Philosophy OF ARISTOTLE 11 (J.L. Creed \& A.E. Wardman trans., Mentor Books 1963). Bambrough notes that "the importance of Aristotle in the intellectual history of Europe is too well known to need explanation or defense." Id.

7. As John Stuart Mill recognized, "no less an intellect, and one which contributed no less to the progress of human thought, than Aristotle, held this opinion without doubt or misgiving" and justified his opinion on the premise that there are "different natures among mankind, free natures, and slave natures.” JOHN STUART MILL, ON LIBERTY AND OTHER WRITINGS 129 (Stefan Collini ed., Cambridge Univ. Press 1989) (1869).

8. 2 ARistotle, The COMPlete Works of Aristotle 2131 (Jonathan Barnes ed., rev. Oxford ed. 1984)

9. See generally MILL, supra note 7. Mill noted that:

The adoption of this system of inequality never was the result of deliberation, or forethought, or any social ideas, or any notion whatever of what conduced to the benefit of humanity or the good order of society. It arose simply from the fact that from the very earliest twilight of human society, every woman (owing to the value attached to her by men, combined with her inferiority in muscular strength) was found in a state of bondage to some man. Laws and systems of polity always begin by recognising the relations they find already existing between individuals. They convert what was a mere physical fact into a legal right, give it the sanction of society, and principally aim at the substitution of public and organised means of asserting and protecting these rights, instead of the irregular and lawless conflict of physical strength. Those who had already been compelled to obedience became in this manner legally bound to it.

Id. at 123 .

10. See generally Nadine Taub \& Elizabeth M. Schneider, Women's Subordination and the Role of the Law, in The Politics OF LAW: A PROGRessive CriTiQUe 151-57 (David Kairys ed., rev. ed. 1990). 
vote or for married women to control their own property or to make their own contracts. ${ }^{11}$ Although feminist theory already has exposed bias in many facets of contemporary life and the world has changed significantly since the mid-1800s, vestiges of male thinking remain in the legal system, particularly in the criminal law. For example, to this day, criminal penalties are much more severe for stranger violence than for domestic violence, or for stranger rape than for marital rape. ${ }^{12}$ The law continues to differentiate between protecting women inside the home and outside the home.

The result of this different treatment severely limits the participation of many citizens in our democratic government. First, women, when treated as objects in need of protection, are discouraged from further engaging in public discourse. The result is to perpetuate traditionally male ways of thinking that offer only limited views of the world, boiling choices down to black and white and imposing universalisms where context is more appropriate. Feminist theory allows us to pay more attention to bias and power disparity. By extension, we can then recognize other biases permeating our system, including racism and classism. As Katharine Bartlett notes, being feminist means owning up to the part one plays in a sexist society and taking responsibility for the existence and transformation of "our gendered identity, our politics, and our choices." through united opposition to the procedures that disempower these marginalized groups that the system can be changed to become more representative.

III

\section{FEMINIST PERSPECTIVES ON CRIMINAL LAW}

The discussion to come about what feminist theory has to offer to the capital punishment debate is informed by looking at two well-known feminist theories: different voice theory and dominance theory. ${ }^{14}$ Although at first glance these two theories appear to be at odds, they both offer insight into how universal and so-called "neutral" standards hide unequal power relationships. Likewise, both theories shed light on the decision to reinstate the death penalty in the United States, on the procedural defects present in current capital punishment law, and on ways to modify the system.

\section{A. Different Voice Theory}

Within different voice theory, "women's differences are viewed . . . as a potentially valuable resource that might serve as a better model of social organiza-

11. See id.

12. See infra Part V.

13. Katharine Bartlett, Feminist Legal Methods, 103 HARV. L. REV. 829, 833 (1990).

14. See generally KATHARINE BARTLETT \& ANGEla HARRIS, Gender AND LAw: THEORY, DOCTRINE, COMMENTARY 487-791 (2d ed. 1998). Feminism is a rich concept that has been defined in relation to countless other disciplines, perspectives, and objectives. These two "subcategories" offer only two of many potential perspectives on capital punishment. 
tion and law than existing 'male' characteristics and values." ${ }^{15}$ The model is premised on the notion that current law and legal theory have been based on an exclusively male model of the world" that characterizes "male" and "female" thought along one fairly clear line: "Women are actually or potentially materially connected to other human life. Men aren't." ${ }^{, 17}$ The result, according to psychologist Carol Gilligan, the mother of the different-voice model, is a creation of two different ways to conceptualize the rights of citizens: the "ethic of justice" and the "ethic of care." "18

Different-voice feminism defines itself in opposition to the traditionally male "ethic of justice," which embodies the dominant rationality and methodology of American law. ${ }^{19}$ This tradition finds its roots in philosophies like those of Immanuel Kant in the Groundwork of the Metaphysics of Morals. There, Kant equates the highest and unconditional good with acts arising not out of kindness, but out of duty. ${ }^{20}$ The genuinely moral person is one who, though "cold in temperament and indifferent to the suffering of others... does good, not from inclination, but from duty." ${ }^{21}$ As aptly voiced by the American jurist Oliver Wendell Holmes, "[t]he justice-oriented problem-solver seeks a distanced stance from which to make objective decisions by applying formal rules of equality and other principles of justice."22 Justice Holmes went on to remark that, when lawyers in his courtroom made appeals to justice, he stopped listening: "[S]uch appeals do nothing but signal that the lawyer has neither the facts nor law on his side, or worse, that he is ignorant of whatever law might be relevant." ${ }^{23}$ Recently, Justice Anthony Scalia reiterated his respect for this method of resolving disputes. In his dissent from the Court's recent decision in PGA Tour, Inc. v. Martin, he argued that the majority opinion "exercises a benevolent compassion that the law does not place it within our power to impose." When pressed to explain his use of the phrase "benevolent compassion," Justice Scalia noted that he was stressing the "social-outreach, maternalistic, goo-goo characteristic of the court's compassion." 25

\footnotetext{
15. Id. at 705 .

16. See Robin West, Jurisprudence and Gender, 55 U. CHI. L. REV. 1, 5 (1988) ("[A]ll of our modern legal theory ... is essentially and irretrievably masculine.")

17. Id. at 14 .

18. Leslie Bender, From Gender Difference to Feminist Solidarity: Using Carol Gilligan and an Ethic of Care in Law, 15 VT. L. REV. 1, 36-37 (1990).

19. Id. at 36 (noting that "[t]raditionally, this perspective was deemed the highest stage of moral development, and it has monopolized legal reasoning").

20. See Robin West, Justice and Care, 70 ST. JOHN's L. REV. 31, 36-37 (1996) (citing LEE DIMOCK, RESIDUES OF JUSTICE (1996)).

21. ImMANUEL KANT, GROUNDWORK OF THE METAPHYSICS OF MORALS 66 (H.J. Patton trans., Harper \& Row 1958) ("[I]t is precisely in this that the worth of character begins to show-a moral worth and beyond all comparison the highest.").

22. Bender, supra note 18, at 37.

23. Robin West, Toward Humanistic Theories of Legal Justice, 10 CARDOzO STUD. L. \& Literature 147, 147 (1998); Oliver Wendell Holmes: His BOOK Notices AND UnCOLleCted PAPERS 201 (Harry C. Shriver ed., 1936)

24. PGA Tour, Inc. v. Martin, 121 S. Ct. 1879, 1898 (2001).

25. William Safire, On Language: Compassion, N.Y. TimES, July 15, 2001, § 6 (Magazine), at 24.
} 
Different-voice theorists criticize the ethic of justice for its disjunction with individual people and circumstances. For example, in the context of capital punishment, the model uses judge-made law and statutes to weigh the competing rights that are in dispute. Individual circumstances are stripped out of the equation, and each crime is boiled down to its bare criminal elements. If there are no constitutionally-prescribed exceptions to capital punishment, we appropriately apply the death penalty. If a defendant's particular circumstances do not fall within this carefully delineated model, we must bend it to fit the model.

In applying these cold and reasoned calculations that are devoid of any human element, legal thinking embraces the "ethic of justice." Different-voice feminists argue that this so-called Rule of Law and the notions of rationality and objectivity are really codes for a conception of social order based on patriarchal beliefs. ${ }^{26}$ These beliefs are perpetuated by those who teach and interpret the laws: The result is that, even though women have become part of the discipline of law, they relearn the world through the eyes of men, discounting traditional "female" characteristics such as emotion and empathy. ${ }^{27}$

An illustration of the male-produced Rule of Law at its most infant stage emerges in Lani Guinier's study on women in law school. ${ }^{28}$ Guinier found that many female law students felt that "learning to think like a lawyer means learning to think and act like a man. As one male professor told a first-year class, 'To be a good lawyer, behave like a gentleman."' 29 In law school, and by extension in the legal world, behaving "like a gentleman" means adopting a standardized, hierarchical, competitive approach that evolves into a game that opponents play to win: "You win when you silence your opponent." In this fight to prevail, the task is not to listen and respond to the perspectives of others, but to divorce emotion from circumstance and to manipulate individual lives into black letter law. ${ }^{31}$

In reaction to the influence of the "ethic of justice," different-voice feminists argue that a second model exists for conceptualizing relationships. They have coined this model the aforementioned "ethic of care"-premised on a more traditionally female means of understanding problems. ${ }^{32}$ Rather than employing an objective stance with formal rules, the care model focuses attention on

26. West, supra note 20 , at $36-38$. It is important to articulate that this method of feminist reasoning is not the polar opposite of a "male" deductive model of legal reasoning. See Bartlett, supra note 11 , at 855-56. It would not be accurate to divide both models into a stark black-and-white contrast between generalization and individualism. Both models put facts into some sort of context and use that context to draw conclusions about a case. The difference is that the ethic-of-care model considers a broader context than is traditionally considered in current legal procedure. The method seeks to uncover perspectives that have traditionally been ignored or discarded by the fact-finder in resolving a conflict. See id.

27. See, e.g., LANi GUINIER ET AL., BECOMING GENTLEMEN (1997).

28. See id.

29. Id. at 29 .

30. Id. at 13

31. Id. at 13-14.

32. Bender, supra note 18 , at 36-37. 
the context of the dispute and the parties' ongoing relationships and interdependencies. ${ }^{33}$ The care model problem-solver looks beyond the immediate facts and asks questions that are not usually present in the typical legal setting. ${ }^{34}$ She must consider the articulated needs of all parties in the dispute and balance the merits of various solutions as opposed to relying on abstract rights and universal rules. $^{35}$ By legitimizing the role of empathy and context in the criminal justice system, the model would allow the consideration of factors not typically heard in the legal process. Robin West perhaps best illustrates the ethic of care model through imagery of

a mother's protective and nurturing embrace of her newborn. Her posture is not upright, but curved. To nurture and protect her child, she makes herself into an "O" ... a mother provides care, protection, warmth, comfort, and love to her newborn, not through the independent linearity of a morally upright pillar of strength, but through the interwoven, interdependent strength of the circle of care. ${ }^{36}$

Ultimately, the goal is to formulate a criminal justice system that fits the individual defendant and that addresses the needs of the victim and the community, as opposed to finding a way to fit the individual into the appropriate model.

The different-voice model, or "difference model," falls short in some significant respects. The first is the concern, voiced by many feminists, that attributing the care model to women will reinforce sex-linked stereotypes and limit women to the role of care-givers and nurturers. ${ }^{37}$ Some feminists argue that celebrating these characteristics as female is in fact solidifying a system that imposes these characteristics on women and masks their true identity. ${ }^{38}$ The risk is that the role of women will be further discounted in the "rational" world dominated by men and that the model implies that women are biologically incapable of applying legal reasoning.

Additionally, this paradigm encounters some difficulty when we try to pinpoint whose voice should be amplified. The model ideally seeks a compromise between competing voices-a solution that fits into the context in which the crime was committed and in which both the victim and the offender stand. The outstanding question is whether a satisfactory conclusion can be reached that can address both points of view. There may be some circumstances where the parties stand at such opposite ends from one another that providing a solution that takes into account one viewpoint may necessarily disadvantage the other. The different-voice model does not instruct us on how to resolve such a conflict.

33. Robin West argues that "we are in the process of covering not only our country but increasingly the world with a conception of adjudicative law pointed only to the interconnected virtues of corporate wealth, individual decisional liberty, and, when not trumped by the universalist mandate of wealth, of moral and cultural relativism." West, supra note 23, at 149.

34. Bender, supra note 18, at 36-37.

35. Id. at 37.

36. West, supra note 20, at 36.

37. Bender, supra note 18 , at 39-42.

38. See, e.g., the philosophies of Catherine MacKinnon, discussed infra p. 266-69. 
Instead, this model focuses on individual dilemmas and conflicts that are overlooked in more abstract legal reasoning. ${ }^{39}$

Despite these shortcomings, there is evidence that the current legal system is premised on a view of the world that largely rejects these characteristics altogether. Incorporating these values into legal procedure and dispute resolution, particularly in the context of capital cases, could lead to more universalistic and fair results. As Bender notes, "[c]aring and cooperation are quintessential values and should be promoted and nurtured in our society, even if historically their work has been unduly, unfairly, and disproportionately foisted upon women." ${ }^{40}$ By revaluing these traits in our legal system, they can be promoted and maintained through the Rule of Law just as rationality and generalized universalism have been.

\section{B. Dominance Theory}

In a discussion of the death penalty, dominance theory, epitomized by the writings of Catharine MacKinnon, adds to difference theory the idea that male privilege is so embedded in our society in general and the legal system in particular that it cannot be distinguished from, and indeed is, the Rule of Law. ${ }^{41}$ MacKinnon criticizes difference theory because of her belief that emphasizing difference reinforces the subordination of women and locks women into a dichotomy originally created and perpetuated by men. ${ }^{42}$ The difference model ultimately legitimizes the civil inequality of the sexes and leads to acceptance of biological difference as a means of upholding the system. ${ }^{43}$ Women reinforce the paradigm when they seek recognition of their differences because they must present themselves as in need of "protection" by the dominant power."

Dominance theorists are particularly critical of "gender neutral" or so-called objective approaches to the law as codes for embracing male conceptions of objectivity and neutrality. "Equality," according to this standard, affirms spe-

39. Bartlett, supra note 13 , at 850.

40. Bender, supra note 18 , at 42.

41. See generally CATHARINE MACKINNON, FEMINISM UNMODIFIED: DisCOURSES ON LiFE AND LAW (1987); see also BARTLETT \& HARRIS, supra note 14, at 487-702 (refering to the same concept as the "nonsubordination" perspective on women and law).

42. MACKInNON, supra note 41, at 32-45. MacKinnon notes that

women value care because men have valued us according to the care we give them, and we could probably use some. Women think in relational terms because our existence is defined in relation to men .... All I am saying is that the damage of sexism is real, and reifying that into differences is an insult to our possibilities. Id. at 39 .

43. Id.

44. Id. at 38-39 (discussing Carol Gilligan's view on gender differences).

45. See, e.g., Kathryn Abrams, Gender Discrimination and the Transformation of Workplace Norms, 42 VAND. L. REV. 1183, 1207-09 (1989) (discussing how, despite the quest of women to be treated the same as men, sexual harassment in the workplace acts as a reminder to women that the sexes remain radically unequal, and a woman is often viewed as an object of sexual derision rather than as a credible coworker). MacKinnon argues that the question of women in the military draft provides another example of the sameness answer to the sex equality question. See MACKINNON, supra note 41, 
cific white male cultural values as the appropriate standard. ${ }^{46}$ Consequently, for women to gain access to the privileges traditionally afforded men, they must submissively adopt "male" principles as their own. ${ }^{47}$ Requiring that women emulate male thinking glosses over the different experiences of women and insufficiently addresses the root of discrimination. ${ }^{48}$

Dominance feminists criticize current sex discrimination law as a combination of gender-neutral and difference standards that simply do not go far enough in addressing the pervasive gender inequities in our system. While very few women succeed at achieving access to privileges traditionally afforded men, women continue to lose their "traditional" rights to men who assert claims under the gender-neutral standard. ${ }^{49}$ One salient example surfaces in the law of rape. If women emulate traditional male notions of vengeance and retribution, they should seek recompense for violations committed against them. ${ }^{50}$ Under a gender-neutral standard, women should demand respect for violation of their bodies by imposing the harshest punishment available-a penalty less than death would devalue women.

Using a dominance analysis, focusing first on the question whether death is the feminist response to rape is misleading. Meting out equal punishment for equally destructive acts only reinforces the notion that the traditional views on punishment should be universal views. This perspective dims the nuances of how rape uniquely impacts a woman's sense of being. For these reasons, recent initiatives to reform rape law have been directed toward making the system more sensitive and more responsive, yet have done little to address the question of why women are raped in the first place. ${ }^{51}$ MacKinnon argues that such changes only make the law more progressive, and do little to make it more feminist. ${ }^{52}$ If we attempt to apply so-called neutral standards, then we will obscure the characteristics of rape that mark its role in the power dynamics between men and women and further legitimize male control over women's sexuality.

Considering this concept in the context of who is implicated in many rape cases further illustrates this point. MacKinnon writes, "[t]o the extent possession is the point of sex, rape is sex with a woman who is not yours, unless the act

at 32-34 ("[G]ender neutrality is thus simply the male standard, and the special protection rule is simply the female standard, but do not be deceived: masculinity, or maleness, is the referent for both.").

46. MACKINNON, supra note 41, at 34.

47. Id. at 37-38. To extend Kathryn Abrams' argument regarding gender discrimination in the workplace would mean that women must act like men to earn the respect of male coworkers. See GUINIER, supra note 27.

48. MACKINNON, supra note 41, at 39-40.

49. Id. at 35-37.

50. Marc Tushnet, Constitutional Issues: The Death Penalty 3-5 (1994) (discussing the role of deterrence and retribution in thinking about the death penalty).

51. Catharine MacKinnon, Feminism, Marxism, Method, and the State: Toward Feminist Jurisprudence, 8 SIGNS 635, 642-45 (1983).

52. Id. 
is so as to make her yours." ${ }^{, 53}$ Statistically, most rapes are by a man the woman knows. ${ }^{54}$ Most rapes are intra-racial, rather than interracial; rapes in which black men are the perpetrators and white women are the victims account for the smallest number of reported rapes. ${ }^{55}$ Yet, statistics continue to show that African-American men convicted of raping and murdering white women are significantly more likely to be sentenced to death than men who rape and murder African-American women. ${ }^{56}$ MacKinnon explains this phenomenon by arguing that these crimes "have two qualities: they are by a stranger, and they are by a black man. These two elements give you the white male archetype of rape." ${ }^{, 57}$ These images simultaneously invoke the patriarchal notion of women as property of white men in need of protection on the one hand, and play into the racist stereotype of black men as defilers of white womanhood on the other. ${ }^{58}$

MacKinnon's philosophy on the subjugation of women through malefocused law translates into philosophies exposing the subjugation of the poor and people of color. Her analysis of rape and race exposes the way in which the existing social order subjugates black men as well as women. While MacKinnon limits her analysis to women, it quickly becomes clear that the experiences of all "others" (that is, those other than white men) have been silenced out of the legal system, because those creating the system do not feel these experiences. Simply adapting the existing standard to people who traditionally have been marginalized by this system will not sufficiently address its inherent problems. Using existing legal tools created and conceptualized by men of power will never succeed in undermining or truly equalizing that system.

Accordingly, MacKinnon advances a new standard by which sex discrimination should be viewed, a standard she labels "radical feminism" or the "dominance approach." ${ }^{59}$ Radical feminism defines sex equality by addressing the power dynamics of submission and dominance that characterize the sexes. It is a standard that "criticizes all the ways [women] have been created by being excluded and kept down but that also claims the validity of [women's] experi-

53. Id. at 645 .

54. MaCKinnon, supra note 41, at 81 (citing DiAna E.H. Russell, SEXUAl ExPloitation: RAPE, Child SEXUAL ABUSE, AND WORKPLACE HARASSMENT, 90-93 (1984)).

55. Elizabeth Iglesias, Rape, Race, and Representation: The Power of Discourse, Discourses of Power, and the Reconstruction of Heterosexuality, 49 VAND. L. REV. 868, 881 (1996) (citing GARY D. LAFREE, RAPE AND CRIMINAL JUSTICE: THE SOCIAL CONSTRUCTION OF SEXUAL ASSAULT (1989)).

56. Phyllis L. Crocker, Is the Death Penalty Good for Women?, 4 BUFF. L. REV. 917, 928-43 (2001); see also TUSHNET, supra note 50, at 36. Tushnet cites the Inc. Fund study that found in the mid-1960s that African-American men convicted of rape were times more likely to be sentenced to death than white men, and that African-American men convicted of raping white women were eighteen times more likely to be sentenced to death than any other combination. This evidence was presented before the Supreme Court in Maxwell v. Bishop, 398 U.S. 262 (1970). For a discussion of the Maxwell litigation, see Michael Meltsner, Cruel and Unusual: The Supreme Court and Capital PUNISHMENT 86-105, 149-67, 199-213 (1973). It is important to note that rape alone no longer serves as a justification for capital punishment.

57. MACKINNON, supra note 41 , at 81 .

58. See id.

59. Id. at $40-45$. 
ence[s]." ${ }^{\circ 0}$ MacKinnon argues that "gender is an inequality first, constructed as a socially relevant differentiation in order to keep that inequality in place[;] the sex inequality questions are questions of systematic dominance, of male supremacy, which is not at all abstract and is anything but a mistake." ${ }^{\circ 1}$ To reconceptualize the system outside of male dominance requires a radical shift away from the male construction of female freedom.

Although dominance theory exposes the gender and power inequities in our system, it imposes nearly impossible hurdles to overcoming the inequality in society. If all people, including women, have been socialized by the system to accept its underlying gender biases, how can we escape the patriarchy or even contemplate these changes? Who is untainted enough by the current system to be qualified to implement these changes? ${ }^{62}$ And how do we avoid substituting one power structure for another, specifically a power structure that is "woman" but otherwise white, middle class, and heterosexual $?^{63}$ Dominance theory offers no real answer to these questions, but it provides a means to question the underlying system and to expose its failings.

\section{Developing a Method to Critique the Death Penalty}

Both different voice feminist theory and dominance theory offer something to the debate on the death penalty. Central to both theories is the tenet that the current system is one that is male, propertied, and white, largely excluding the voices of those it processes through its courts and prisons. Regardless whether dominance or different voice theory is adopted, considering legal issues from a feminist perspective "means looking beneath the surface of law to identify the gender implications of rules and the assumptions underlying them and insisting upon applications of rules that do not perpetuate woman's subordination." ${ }^{64}$ It demands "special attention to a set of interests and concerns that otherwise might be, and historically have been, overlooked." ${ }^{65}$ Finally, feminist analyses of legal decisionmaking have revealed that the so-called neutral means of deciding cases tend to mask, not eliminate, political and social considerations from legal decisionmaking. These "neutral" or "objective" means are not truly neutral, but are instead driven by a different set of emotional variables that are so ancient, that they have become invisible.

60. Id. at 120 .

61. Id. at 42 .

62. See MacKinnon, supra note 51, at 642-45 (arguing that women suffer from a false consciousness approach that is evidence of their stake in their own oppression).

63. See BARTLETT \& HARRIS, supra note 14, at 1007-09; see also Angela Harris, Race and Essentialism in Feminist Legal Theory, 42 STAN. L. REV. 581 (1990).

64. Bartlett, supra note 13 , at 843.

65. Id. at 846 . 
IV

\section{APPLYING FEMINIST REASONING TO THE CURRENT SYSTEM}

If we apply the feminist methodology defined above to the death penalty as it exists in the United States today, we must conclude that the current system, like most criminal justice policy, follows the same patterns in which the perspective of women is absent-except as the protected beneficiary of the law. This section of this note will address the wisdom of the Supreme Court's decision, after a brief hiatus, to hold that the death penalty is a constitutional form of punishment.

In colonial times, statutes authorized capital punishment for a host of crimes in England and the colonies, including murder, arson, rape, robbery, kidnapping and several other offenses. ${ }^{66}$ In fact, before the 1790 s, the death penalty was mandatory for specified crimes; it was not until the nineteenth century that states began to whittle away at mandatory death sentences by creating degrees of murder and jury discretion. ${ }^{67}$ Although the number of executions peaked in 1935 at 199 nationwide, the number began to decrease slowly, falling to half that number by the 1960 s. $^{68}$ The Supreme Court's handling of capital punishment cases in the 1960s likewise reflected deep ambivalence among the justices, particularly marked by their vacillation on the question whether a separate sentencing hearing was required. ${ }^{69}$ Because of the dramatic changes in the attitude of society and of the Court, it is noteworthy to identify the basis of the changes and its relevance to feminism.

In 1972, the Supreme Court took its most dramatic and decisive step in addressing the death penalty. The Court decided to hear four cases in which the justices would address the question whether the death penalty was a violation of the Eighth Amendment right to be free from cruel and unusual punishment. ${ }^{70}$ Of the capital cases it eventually heard, two involved not murder, but rape, and one involved an accidental killing. The case of the accidental killing was Furman v. Georgia, in which the defendant, William Furman, suffering from psy-

66. TUSHNET, supra note 50, at 19-20. For an overview of the development of capital punishment in the United States, see GlenN Pierce AND JoHn F. MCDEvitT, LEGAl Homicide: DeATH AS PUNISHMENT IN AMERICA, 1864-1982 (1984) and VOICES AGAINST DEATH: AMERICAN OPPOSITION TO CAPITAL PUNISHMENT, 1787-1975, xi-xiii (Philip English Mackey ed., 1976).

67. TUSHNET, supra note 50, at 22.

68. $I d$.

69. See Bob Woodward And Scott Armstrong, The Brethren 242-47 (1979) (noting the Court's secret vote to strike down the Arkansas death penalty in Maxwell v. Bishop and the Court's subsequent decision in McGautha v. California to uphold current capital procedure without a bifurcated trial); see also TUSHNET, supra note 50, at 37-40.

70. The four cases to be heard were Aikens v. California, 403 U.S. 952 (1971), Furman v. Georgia, 403 U.S. 952 (1971), Branch v. Texas, 403 U.S. 952 (1971), and Jackson v. Georgia, 403 U.S. 952 (1971). See John Poulos, The Supreme Court, Capital Punishment and the Substantive Criminal Law: The Rise and Fall of Mandatory Capital Punishment, 28 ARIZ. L. REV. 143, 172 (1986); see also WOODWARD \& ARMSTRONG, supra note 70, at 242. About the same time that the Court decided to hear oral arguments, the California Supreme Court found the death penalty unconstitutional under the state constitution, and thus Aikens no longer faced the death penalty. Consequently, the Supreme Court dismissed his case. See People v. Aikens, 406 U.S. 813 (1972); TUSHNET, supra note 50, at 47. 
chotic episodes, broke into William Micke's house late at night. ${ }^{71}$ When Micke came downstairs to investigate, Furman fled the scene, tripped over an electrical cord, and accidentally fired the gun he was carrying through the closed door of the house. The shot killed Micke. ${ }^{72}$

The Court was terribly divided over the imposition of capital sentencing and ultimately voted 5-4 in Furman against the death penalty. The Furman decision was announced on the last day of the term, and each of the justices wrote his own opinion. The result totaled 50,000 words and 243 pages- the longest decision in the Court's history. ${ }^{73}$ The bases for the opinion were varied. Justice Thurgood Marshall and Justice William Brennan wrote the most unequivocal condemnations of capital punishment. Justice Brennan found that capital punishment failed to pass constitutional muster based on four principles that he believed were essential to determine the constitutionality of punishment: The punishment must comport with human dignity; it must not be arbitrary; it must not be unacceptable to contemporary society; and finally, it must not by its severity be degrading to human dignity. ${ }^{74}$

Justice Marshall painted a broader condemnation of the punishment, arguing that "retaliation, vengeance, and retribution" were not acceptable "aspirations for ... a free society." 75 He cited the discriminatory impact of the death penalty on the poor, the ignorant, and the underprivileged, and argued that our standards of decency had evolved to the point where capital punishment could not be upheld. ${ }^{76}$ Justice Marshall also specifically noted the unequal treatment of men and women in the face of capital punishment, but argued that "so long as the capital sanction is used only against ... easily forgotten members of society, legislators are content to maintain the status quo." $" 77$

The separate concurring opinions of Justices William Douglas, Potter Stewart, and Byron White used far different rationales for striking down capital punishment under these circumstances. These three justices appeared to be more swayed by the arbitrary nature of the death penalty, rather than concluding that the punishment per se violated the Eighth Amendment. Justice Stewart noted that "the Eighth and Fourteenth Amendments cannot tolerate the infliction of a sentence of death under legal systems that permit this unique penalty to be so wantonly and so freakishly imposed." ${ }^{178}$ Justice White echoed that the infrequent imposition of the death penalty and the lack of a meaningful basis for distinguishing those cases in which the penalty was imposed created flaws in the discretionary sentencing schemes. ${ }^{79}$ Justice Douglas specifically re- $^{-}$

71. 167 S.E.2d 628 (1969).

72. Furman v. Georgia, 408 U.S. 238, 295 (1972).

73. WOODWARD \& ARMSTRONG, supra note 69, at 260.

74. Furman, 408 U.S. at 269-82.

75. Id. at 343 (Marshall, J., concurring).

76. Id. at 364 (Marshall, J., concurring); see also id. at 249-50 (Douglas, J., concurring).

77. Id. at 366 (Marshall, J., concurring).

78. Id. at 310 (Stewart, J., concurring).

79. Id. at 311-13 (White, J., concurring). 
frained from deciding whether imposition of the death penalty at all would be constitutional. Rather, he limited his concurrence to the idea that the discretionary statutes were unconstitutional because they were full of discrimination inconsistent with the idea of equal protection of the laws. ${ }^{80}$

A. The Failure of Furman to Get to the Heart of the Debate

Despite the recognition by the Supreme Court of the disparate impact of the death penalty on different members of society, the problem with the Furman decision, from a feminist point of view, is that it left too much leeway for our patriarchal society to fill in the gaps. Although Justices Douglas and Marshall focused on discrimination in death sentencing, the grant of certiorari was limited to the question whether the imposition and implementation of the death penalty constituted cruel and unusual punishment, not the broader implications of discrimination and its impetus. ${ }^{81}$ Likewise, although Justice Douglas believed that the fatal flaw in capital sentencing was granting unfettered discretion to judges and to the jury because it allowed them to act on their prejudices, he did not question whether the system itself might be biased against those already marginalized. ${ }^{82}$ Accordingly, subsequent case law focused not on ending discrimination, but on limiting the "unbridled discretion" of the jury. If states could add a level of predictability to the calculation and limit the discretion of the jury in some way, the penalty could pass muster. ${ }^{83}$

The second problem with Furman was that the language of the decision failed to press the sentencing process beyond its normative limits. Justice Brennan's concurrence, arguably one of the more far-reaching opinions, noted that the punishment must "not be unacceptable to contemporary society" to "make certain that the judicial determination is objective as possible," ${ }^{, 4}$ but failed to address the question of who speaks for contemporary society in determining what is or is not acceptable. His opinion failed in particular to note that contemporary society in many parts of the country still sanctioned racial segregation. Justice Brennan never questioned why contemporary society continued to punish poor men of color much more harshly than other members of its society.

The majority opinions, while important for their principled stance against the problems in capital sentencing, did not transcend classical "male" reasoning. Feminist practical reasoning, by contrast, challenges the legitimacy of the norms of those who claim to speak, through rules, for the community. This reasoning is premised on the belief that there is not one, "but many overlapping commu-

80. Id. at 256-57 (Douglas, J., concurring).

81. Poulos, supra note 70 , at 172.

82. Id. at 173 .

83. In light of this point, it is particularly interesting to note that the reaction of the states was to enact mandatory capital sentencing laws that eliminated all jury discretion. See infra Part IV.B.

84. Furman, 408 U.S. at 277. 
nities to which one might look for "reason." ${ }^{85}$ The Court did not consider who purported to speak for the community. Nor did any of the Justices really question who set the standard of objectivity. If so, they may have realized that they had essentially reiterated traditional male thinking that fell short of recognizing the perspective of the very people most affected by its decision.

Likewise, the Justices applied "formal rules of equality and other principles of justice," but did not look beyond the immediate facts of each case. The Justices attempted to create universal rules that would address the problem without realizing that abstract, universal reasoning could never address the layers of prejudice and discrimination in the system. To achieve a more feminist system (admittedly, a goal they were not trying to reach), the Justices would have had to acknowledge the limits of the current trial system in which the defendant's rights were juxtaposed against the government's goals within the context of a primarily white, male, middle-class society.

The tension between the opinions of the Justices centered on which standards should serve as the appropriate measure of the sentence's constitutionality. While the Justices writing the majority opinions attempted to transcend traditional black-letter law to incorporate the impact of fundamental injustice, the application of the laws, in the end, limited true contextual thinking. Without questioning the premise, the result is to disallow the language of emotion and to divorce human experience from the sentence that is imposed. ${ }^{86}$ This shortcoming is seen more starkly in the reasoning of Justice Harry Blackmun's dissent in Furman. As Justice Blackmun noted, despite his "distaste, antipathy, and, indeed, abhorrence" for the death penalty, the Court's sole task was:

to pass upon the constitutionality of legislation that has been enacted and that is challenged. ... We should not allow our personal preferences as to the wisdom of legislation and congressional action, or our distaste for such action, to guide our judicial decisions in cases such as these.

Judith Baer argues that the difficulty with statements such as Justice Blackmun's is that emotion and personal preference already exist in the system. ${ }^{88}$ Not only are these emotions cloaked in judges' robes, but the emotions of the victim, offender, and community members cannot be vacuumed out of the equation. At the same time, there is a sanctioned appeal to juror discretion and the imposition of their moral standards. To pretend that the system is truly neutral and not tainted by emotion is dishonest and simply a means of legitimizing the system and rationalizing the consequences.

It is also important to consider how perpetuating this punishment, and this way of thinking, further solidifies patriarchal bias in our criminal justice system.

85. Bartlett, supra note 10 , at 855 .

86. See Lynne Henderson, Legality and Empathy, in FEMINIST JURISPRUDENCE 244, 244 (Patricia Smith ed., 1993).

87. Furman, 408 U.S. at 405, 411.

88. Judith Baer, How is Law Male? A Feminist Perspective on Constitutional Interpretation, in THE DifFERENCE DEBATE: FEMINIST JURISPRUDENCE 147, 155 (Leslie Friedman Goldstein ed., 1992). 
By killing mostly poor men without adequate representation, ${ }^{89}$ we as a society are showing a callous disregard for the plight of marginalized people. We refuse to empathize with the offenders, refuse to consider the context in which their crimes were committed, and, more importantly, refuse to acknowledge our society's role in contributing to violent crime. By imposing shallow means of redress to victims of violence, we are invalidating a series of emotions and a way of thinking that has been characterized as female. Unless we address the feminist implications of the death penalty, we are perpetuating a system of white, male, middle-class bias with the most extreme results for all marginalized groups.

B. After Furman: Cementing the Biases of the Majority in Death Penalty Case Law

The Court's failure to develop a more comprehensive and universal response to the defects in capital punishment policy resulted in the death penalty's revival only a few short years later. The Court relied primarily on two factors in rationalizing societal return to capital sentencing: the role of the state legislatures as representatives of community sentiment and limited sentencing roles of juries. The Court concluded that these factors represented "objective indicia that reflect the public attitude toward a given sanction." ${ }^{\circ 0}$

As the Court noted in Gregg v. Georgia, at least thirty-five states reenacted the death penalty in the years between Furman and Gregg. ${ }^{91}$ The Court used this phenomenon as evidence that many communities did support capital punishment. It concluded that punishment selected by a democratically elected legislature against a constitutional measure would be presumed valid. ${ }^{92}$ Yet the Court never looked closely at the people serving in the state legislatures. The Court never questioned whether these individuals spoke on behalf of all communities, or only the communities that had been represented, to the detriment of others, throughout the history of the United States.

Second, the Court looked to the sentencing decisions of juries as a means to revive capital punishment. In McCleskey $v$. Kemp, the Court specifically considered the role played by jurors and noted that it had been carefully circumscribed by "clear and objective standards so as to produce non-discriminatory application." "93 The Court did not consider that these standards themselves may

89. See Stephen Bright, Essay, Counsel for the Poor: The Death Sentence Not for the Worst Crime But for the Worst Lawyer, 103 YALE L.J. 1835, 1842 (1994) (noting that capital trials are "more like a random flip of the coin than a delicate balancing of the scale" because of ill-trained, unprepared, and grossly underpaid defense lawyers); Samuel R. Cross \& Robert Mauro, Patterns of Death: An Analysis of Racial Disparities in Capital Sentencing and Homicide Victimization, 37 STAN. L. REV. 27 (1984); Ruth E. Friedman, Statistics and Death: The Conspicuous Rose of Race Bias in the Administration of the Death Penalty, 11 LA RAZA L.J. 75, 75-76 (1999) ("[W]hile blacks constitute under 13\% of the American population, they make up $42 \%$ of the over 3,500 inmates on the states' death rows.").

90. McCleskey v. Kemp, 481 U.S. 279, 300 (1987).

91. Gregg v. Georgia, 428 U.S. 153, 179 (1976).

92. Id. at 175 .

93. McCleskey, 481 U.S. at 303. 
not be objective, but may instead reflect bias inherent in the system. Similarly, the Court did not ask why this "non-discriminatory" application was producing skewed and de facto discriminatory results.

Likewise, the Court in McCleskey glorified the jury because of its "diffused impartiality" in considering the facts of the case. The Court set out a laundry list of precautions it had taken to address discrimination in the system, but then essentially concluded that any remaining bias would have to be permitted. ${ }^{94}$ The Court found that the jury sentence reflected the "conscience of the community as applied to the circumstances of a particular offender and offense." Court did not honestly address the limits already in place on capital juriesspecifically that only those who would vote to impose the death penalty could sit on a capital jury in the first place. Already, the population had been reduced to a subset that supported and sanctioned the current rule of law.

Again, we have to ask who is determining these objective criteria that demonstrate a community consensus in support of the death penalty. The Court's reluctance or inability to question the hypothetical or to think outside of the abstract reasoning box exposes a bias that permeates its reasoning. Ultimately, the result of Court decisions after Furman has not been to purge the system of arbitrary and capricious state killings, but rather to cement the biases of the majority into death penalty case law.

\section{$\mathrm{V}$ \\ EVIDENCE OF BIAS}

Parts V and VI of this note address the wisdom of the procedures imposing the death penalty, assuming that the death penalty is constitutional. Part V documents how the capital punishment law remains biased and continues to differentiate based on gender. Part VI exposes how victim impact statements, while an attempt to give context to crime, fail to achieve true equal representation.

\section{A. Discrepancies in Protecting the Public and Private Spheres}

The issue of patriarchal bias is seen perhaps most starkly in the way courts address homicide cases involving domestic partners and those involving more public "stranger" crimes. Feminist literature has long recognized separate sphere ideology in which a public, male sphere is defined in contrast to a private, female sphere. ${ }^{96}$ The male sphere includes that which is concerned with arenas such as government, politics, and business-areas from which women have traditionally been excluded, and which are regulated by the law. In contrast, the law largely has ignored the private sphere-one defined by the home and the family-particularly choosing to turn a blind eye to domestic violence

94. Id. at 310 n.30.

95. Id. at 310 .

96. BARTLETT \& HARRIS, supra note 14 , at 2. 
perpetrated in the home by men. This bias inherent in our system is reflected today in those sitting on death row.

Statistics reveal the bias in the way that the law addresses homicide in the public and private spheres. The majority of those inmates on death row today-at least $75 \%$ - are those who have killed someone in the course of another serious felony. ${ }^{97}$ According to Elizabeth Rapaport, only about $18 \%$ of the total number of homicides involve predatory killings of strangers, but this category accounts for the greatest number of inmates on death row. ${ }^{98}$ Although $28 \%$ of the total number of annual homicides involve the death of intimates or close relatives, only $18 \%$ of those currently on death row are there for such a crime. ${ }^{99}$ In six states studied by Rapaport, only $12 \%$ of the men sentenced to die had killed intimates, while almost $50 \%$ of death-sentenced women were domestic killers. ${ }^{100}$ Additionally, the men and women sent to death row are there for different kinds of domestic crimes. Nearly one-half of the men killed because a woman left the relationship; over two-thirds of the women killed for pecuniary gain - a factor that arguably makes the crime more public. ${ }^{101}$

Even consideration of aggravating and mitigating factors reveals a bias that disproportionately protects people and property from stranger violence. While killing a public official or killing in the course of a predatory felony constitute aggravating factors in capital cases, violence in the home is conspicuously absent from the list. ${ }^{102}$ In those domestic violence cases that do lead to capital sentences, the most common aggravators are extreme brutality, commission during another felony, and multiple murders. ${ }^{103}$

The legal response to domestic killings versus public killings reveals a set of male-privileged priorities codified in the law. The law has created a variety of defenses that provide a way out for those men who murder their intimate partners-for example, recognizing the "heat of passion" defense as a means of mitigating culpability. ${ }^{104}$ This bias is revealed most strikingly in Godfrey $v$. Georgia, ${ }^{105}$ one of the better-known domestic violence homicides. In this case, the petitioner's wife decided to leave the petitioner and move in with her mother to escape what was an undisputedly abusive relationship. ${ }^{106}$ She brought aggravated assault charges against her husband and filed for divorce. Her husband pursued her and ultimately found her at her mother's house, where he

97. Elizabeth Rapaport, Capital Murder and the Domestic Discount: A Study of Capital Domestic Murder in the Post-Furman Era, 49 SMU L. REV. 1507, 1510 (1996).

98. Id.

99. Id.

100. Id. at 1517 .

101. Id.

102. Id. at 1511-13.

103. Id. at 1515 tbl. 1 . 1958).

104. See, e.g., State v. Ott, 686 P.2d 1001 (Or. 1984); Belton v. Commonwealth, 104 S.E.2d 1 (Va.

105. 446 U.S. 420 (1980).

106. Id. at 424 . 
killed both her and her mother with a shotgun. ${ }^{107}$ The issue that marks this case is the question whether the murder was "unambiguously 'outrageously or wantonly vile, horrible or inhuman" so as to warrant the death penalty. ${ }^{108}$ The court found that it was not. Additionally, "Justice Stewart appears to go further, suggesting that domestic murder cases are inherently run-of-the-mill" when compared to capital murders, arguing that because his victims were killed instantaneously and were "members of his family who were causing him extreme emotional trauma," his crime was no more depraved than any other murder. ${ }^{109}$ This sort of rationale for discounting domestic murders is not uncommon. At least three states-North Carolina, Illinois, and Florida-have a judiciallycreated exemption from capital punishment for domestic separation murderers. ${ }^{110}$

From a feminist perspective, the legislative and judicial responses to domestic violence homicides reveal an intrinsic bias within the system. It cannot be ignored that married women traditionally were considered the property of their husbands and that, in general, the legal system would not interfere with a man's treatment of his spouse. If a man went too far and actually killed his wife, the "law frowned on it, but this was a minor offense when compared with that of a woman killing her husband, a treasonous act for which the woman would be burnt alive." 111 As noted in the 19th century North Carolina Supreme Court case State v. Rhodes, ${ }^{112}$ "[w]e will not inflict upon society the greater evil of raising the curtain upon domestic privacy, to punish the lesser evil of trifling violence." While the law no longer explicitly sanctions domestic violence, the disparate treatment between wife- and-husband killings persists today. In addition to different capital penalties, men who kill their partners spend an average of two to six years in prison. Women convicted of killing their partners spend an average of fifteen years behind bars. ${ }^{114}$

These statistics reveal that, within the legal system, it has become acceptable to limit the intrusion of the capital law into the family. According to dominance theory, the result is to filter the perspective of women out of the legal parameters: It silences the experiences of women out of the equation. Cloaking this treatment of women in the "Rule of Law" imposed by "objective" judges legitimizes female powerlessness and sanctions the way that women are treated.

This public/private dichotomy exposes gender bias inherent in the system. This bias also emerges in the way that women offenders are treated within the

107. Id. at 425 .

108. Martha Mahoney, Legal Images of Battered Women, 90 MICH. L. REV. 1, 72 (quoting Godfrey, 446 U.S. at 432).

109. Rapaport, supra note 97 , at 1521 (quoting Godfrey, 446 U.S. 433).

110. Id. at 1522-30.

111. Maryanne E. Kampmann, The Legal Victimization of Battered Women, 15 WoMEN's RTS. L. REP. 101, 102 (1993).

112. 61 N.C. 453 (1868).

113. Id. at 459 .

114. Kampmann, supra note 111, at 101. 
capital system. Rapaport notes that "there are deep cultural inhibitions against the deliberate killing of women, even women who have been convicted of heinous murders, which war with the criminal law norm of equality of treatment of cases and the strictures of the fourteenth amendment's equal protection clause." 115 It is true that women rarely commit the kinds of crimes that lead to capital sentences, yet again we must consider which crimes provoke these sentences. For example, women commit only six percent of the felony murders, but they kill spouses and children almost as often as men do. ${ }^{116}$ Rapaport concludes that, "while capital statutes offer their special protection to representatives of the state and to the interaction of non-intimates, the third of the three spheres into which society can be divided, family life, is notably absent from the statute's universe of concerns." 117 The result is a system that "is chivalrous to women as perpetrators, since such a high percentage of the homicides women commit are domestic; but it is not chivalrous to women as victims, since the blameworthiness of domestic homicide is discounted relative to stranger killings." 118

From a different-voice point of view, the fact that the law does so little to protect the "female" sphere, but punishes most harshly the public "male" sphere, reveals the male orientation of the system-both in terms of whom it chooses to punish and whom it chooses to protect. It is particularly revealing if we consider that many of these laws were written when very few women were even integrated into the public sphere. Yet, this dichotomy persists today. In the current criminal justice system, we are more likely to punish the taking of property in the form of robbery-murder than to punish the killing of a spouse or child in anger. ${ }^{119}$ It is notable to consider the contrast in criminal law that protects the sanctity of the home from strangers yet does little to protect the sanctity of the home from co-occupants. For example, some self-defense statutes do not require a man to retreat before using deadly force if he is attacked by a stranger within his home..$^{120}$ Likewise, some states regard an attack within the home by a stranger as an aggravating factor in death penalty cases. ${ }^{121}$ At the same time, an attack by an intimate within the home will usually not be considered a capital crime without a showing of deliberateness, premeditation, or an intent to kill on the part of the offender. ${ }^{122}$

115. Elizabeth Rapaport, Some Questions About Gender and the Death Penalty, 20 GOLDEN GATE U. L. REV. 501, 503 (1990).

116. Id. at 509-10.

117. Id. at 558 .

118. $I d$. at 559 .

119. See id. at 560

120. See, e.g., MASS. GEN. LAwS ch. 278, § 8A; Stuart P. Green, Castles and Carjackers: Proportionality and the Use of Deadly Force in Defense of Dwellings and Vehicles, 1999 U. ILL. L. REV. 1 (describing the history of the castle doctrine).

121. See, e.g., IND. CODE ANN. § 35-50-2-9(b)(15)(Michie Supp. 1997) (aggravating factors include murders committed by intentionally discharging a firearm into an inhabited dwelling).

122. Rapaport, supra note 115 , at 564-65. 
Surely the reason our law has developed as it has in this regard is that men, whose perspectives have shaped the law, have had far less reason to fear their intimates than have women and children, and at the same time, have had an investment in supporting the privileged separateness of the domestic sphere under male authority. ${ }^{123}$

The answer to this dilemma is not to impose capital punishment on domestic violence killers to even the score. As we have seen, to do so would be to play into the hands of those who perpetuate the system and to accept as valid their punishments. The argument instead is one against imposing capital punishment at all. It advocates a different and more equitable system altogether-a system that values the sanctity of the home on all levels.

\section{B. Reflections of Bias in Subsequent Supreme Court Decisions}

1. Mitigating and Aggravating Factors. We do not have to consider cases that directly involve women to document the patriarchal bias pervasive in death penalty jurisprudence. One consequence of resorting to "objective" standards is seen in the debate over who is eligible for death. The Supreme Court rejected standards that granted judges and juries unfettered discretion in sentencing someone to death and likewise struck down laws that prevented juries from exercising any discretion. The Court instead sanctioned the use of aggravating and mitigating factors that juries could weigh in determining whether capital punishment was appropriate. ${ }^{124}$ The Court's reasoning was ostensibly to provide guidance to the juries and to establish some sort of uniform standard that would eliminate the arbitrary nature of the imposition of capital punishment. ${ }^{125}$ However, as Bartlett notes, "facts determine which rules are appropriate and rules determine which facts are relevant." ${ }^{126}$ The rules laid down by the Court and the state legislatures to guide who is sentenced to die are one way in which the state imposes male values codified and validated in a formula that is applied by all jurors. The result is to sanction one perspective that, when cloaked with the authority of the government, appears to lose its subjectivity. Renaming the process as "objective" does not make it so.

What results from imposing this set of "objective" mitigating and aggravating factors is a denial of true discretion and moral responsibility to jurors. It allows prosecutors to make appeals for death sentences in a "dispassionate, lawyerly, legalistic form" in which jurors are urged to apply a fact-finding formula. ${ }^{127}$ Jurors are often led to believe that, if they add the aggravating factors and subtract the mitigating factors, they will arrive at a magic solution that strips them of any moral responsibility for their decision. Robert Weisberg found that the defense narrative is one that is difficult to convey and that the

123. Id. at 565 .

124. See generally Gregg v. Georgia, 428 U.S. 153 (1976).

125. See id.

126. Bartlett, supra note 13 , at 836 .

127. Henderson, supra note 86 , at 248. 
"legalistic formula can provide sanctuary from moral anxiety." take the decision out of the context of the community and to boil it down to an abstract and universal principle. Ultimately, the jurors are repeating and engaging in a system of male legal reasoning and divorcing themselves from the part they play in the process.

The irony in revealing bias in this process is that the Supreme Court explicitly recognized the need for jurors to consider the individualized circumstances of the defendant's life. Specifically, in Lockett v. Ohio, ${ }^{129}$ the Court reiterated its holding that the "sentencing process must permit consideration of the "character and record of the individual offender and the circumstances of the particular offense as a constitutionally indispensable part of the process of inflicting the penalty of death." 130 Yet, subsequent Supreme Court decisions limited the extent to which jurors or the state courts truly had to engage in this process. ${ }^{131}$ Weisberg criticizes the Court's interpretation of this individual consideration, arguing that

the states must have some sort of penalty trial law on their books to fill the embarrassing gap created by Furman. The law must somehow identify a class of deatheligible murderers smaller than the class of all murderers, must give some sentencer some discretion about choosing which of the eligibles to execute, and must grant defendants a fairly broad opportunity to make a case for mitigation. Beyond that, the rule may be of any kind, and the Court will not monitor its enforcement. ${ }^{132}$

2. Disregard for Racial Bias. Other recent death penalty decisions from the Supreme Court reveal a steadfast adherence to "objective" tests and rational results that appear to exclude the viewpoint of marginalized people. For example, in McCleskey v. Kemp ${ }^{133}$ the defendant's attorneys showed the court overwhelming statistical evidence that defendants charged with killing white persons were more likely to be sentenced to die than those who killed black persons. ${ }^{134}$ Those cases in which a black defendant killed a white victim were most likely to result in a death sentence. ${ }^{135}$ Interestingly enough, the Eleventh Circuit in an en banc opinion found that such discriminatory treatment passed constitutional muster. "It would not make sense for the system to require the exercise of discretion in order to be facially constitutional, and at the same time hold a system unconstitutional in application where that discretion achieved different results for what appear to be exact duplicates ...."136 The Eleventh Circuit was more

128. Robert Weisberg, Deregulating Death, 1983 SuP. CT. REV. 379-95 (1983).

129. 438 U.S. 586 (1978).

130. Id. at 601 (citing Woodson v. North Carolina, 428 U.S. 280, 304 (1976) (emphasis added)).

131. See, e.g., Zant v. Stephens, 462 U.S. 862 (1983) (holding that, despite the fact that one of the three aggravating factors was found later to be unconstitutional, all of the evidence would have come in anyway, so the error was harmless); Barclay v. Florida, 463 U.S. 939 (1983) (finding that the judge's discretion was "constitutionally adequate" despite the fact that it may have violated state law).

132. Weisberg, supra note 128, at 358.

133. 481 U.S. 279 (1987).

134. Id. at 286.

135. Id.

136. Id. at 289-90 (citing McCleskey v. Kemp, 753 F.2d 877, 898-99 (1985)). 
up-front in naming the bias prevalent in the system and found that it still fit the Furman test: "In pre-Furman days, there was no rhyme or reason as to who got the death penalty and who did not. But now, in the vast majority of cases, the reasons for a difference are well documented." ${ }^{137}$

The Supreme Court, while assuming the statistical validity of the study, discounted the conclusion that race played into any sentencing decisions in Georgia. The Court would only acknowledge that there was a risk that race entered into some of the capital sentencing decisions. ${ }^{138}$ This risk was insufficient to risk upsetting the entire system. Essentially, the Court practiced typical "male" reasoning as defined by Gilligan-it adopted a distanced stance from the overarching issue and did not look beyond the immediate facts to question the results in McCleskey's, or any other defendant's, case.

Perhaps most revealing of its patriarchal bias, the Court dismissed McCleskey's claim that discrimination "extend[ed] to every actor in the Georgia capital sentencing process, from the prosecutor who sought the death penalty and the jury that imposed the sentence, to the State itself that enacted the capital punishment statute and allows it to remain in effect despite its allegedly discriminatory application." ${ }^{139}$ Justice Lewis Powell seemed to scoff at the notion that such widespread discrimination could exist-never questioning the possibility that the whole system could be pervaded by a system of beliefs that privileged its white sons at the expense of other people. It is further revealing that the Court justified its decision based on the fear that, if they accepted McCleskey's claim that racial bias had tainted the capital sentencing decision, they might have to face similar claims in other penalties where a disproportionate number of defendants were male or people of color. ${ }^{140}$ Fear that an entire system might be tainted is certainly no reason to ignore and, indeed, to perpetuate that taint.

\section{VI}

\section{VICTIM IMPACT STATEMENTS}

One way the state has attempted to equalize the system is to allow the presentation of a victim impact statement. The victim impact statement appears to be consistent with many of the philosophies expounded by feminists-it allows the victim or their family members, who are often marginalized in the criminal justice system to give context and voice to the crime that occurred. It incorporates narrative into a process that is generally full of expert testimony, cross examination, and fact-specific questions. It calls for empathy and gives insight into the impact of the crime in a way that extends beyond the immediate case at trial. In fact, feminist anti-rape groups were among the first to organize and ad-

137. Id.

138. Id. at 292 n.7.

139. Id. at 292 .

140. Id. at 315 . 
vocate on behalf of victims in the $1970 \mathrm{~s}^{141}$ On a national level, the efforts of Candy Lightner, founder of Mothers Against Drunk Driving, "marked the beginning of successful political and social recognition of victims."

The problem with the use of such statements is that they endorse "male" emotions such as anger and vengeance and leave little room for context or for resolutions outside the traditional legal system. As Bartlett notes, "the questions, as always, are: who gets to tell the story and what agenda will the telling serve." ${ }^{143}$ In the case of victim impact stories, it is often the prosecutor who tells the story, already intent on securing a death sentence, to play on the jury's sympathy and to dehumanize the defendant further. The stories are used as a means to trump those rights. In fact, those who support the use of victim impact statements "do not [always] argue for the punishment of the guilty as a duty owed to the individual victim" but "they argue in terms of the duty and right of the state and community to punish." 144

While advocates of victim impact statements may argue that they humanize the victim and her family, the statements often reduce the victim to the crime alone. As Susan Bandes notes, the victim impact statement offers little room for complex and politically liberal narratives. ${ }^{145}$ The statements draw on "stock" victim imagery to feed the imagination of the jury. Instead of providing victims with counseling, support, and concern, the state manipulates the victim's pain into fodder to serve its own agenda. ${ }^{146}$ Likewise, "the unreflective translation of the anger of victims into a desire for retaliatory retribution" might be inaccurate, constituting moral error. ${ }^{147}$

From a feminist perspective, victim impact statements are problematic on many levels. In terms of dominance feminist philosophy, the problem is inherent in the fact that the existing criminal justice system, created by those in power, was not created to empower those who have been silenced. Instead, twisting the experiences of the "other" into conformity with the experiences of those in the majority does not necessarily result in true liberation. Instead, it is an attempt to equalize women's roles by giving them access to male institutions, without addressing the fact that these standards may not be appropriate for all people. For example, the system emphasizes anger, punishment, and revenge. Asking victims to adopt these emotions may not be entirely consistent with their own experience and may be distorting and privileging one set of emotions to the detriment of other emotions. The result is the continued silencing of the experiences that do not fit neatly into this paradigm.

141. See Lynne Henderson, Co-opting Compassion: The Federal Victim's Rights Amendment, 10 ST. THOMAS L. REV. 579, 581 (1998).

142. Id.

143. Katharine Bartlett, Story Telling, 1987 DUKE L.J. 760, 765 (1987).

144. Henderson, supra note 141, at 594.

145. Susan Bandes, Empathy, Narrative, and Victim Impact Statements, 63 U. CHI. L. REV. 361, 405 (1996).

146. See Henderson, supra note 86 , at 276.

147. Id. 
Additionally, sanctifying the role of victim in this process may serve to "revictimize" victims. Particularly in cases involving women, it risks cementing the woman's place on a pedestal where she needs the protection and guidance of the state. Instead of empowering victims, the system can impose upon a woman a set of expectations on how she should react and what she should feel. As Carol Smart has noted, criminal justice reforms can "make women embrace their victim status more warmly." 148 The current use of the victim impact statements "illustrates the emptiness of the concepts of empathy and narrative when they are constrained by extrinsic normative, political, or moral principles." ${ }^{149}$

From a different-voice perspective, the victim impact statement also falls short. While the addition of these statements appears to fit more closely into this feminist theory, in reality, it distorts the philosophy-crediting one voice while silencing the other. Arguably, the defendant can present his own narrative in the form of mitigating evidence, but the procedure itself is skewed in that the result is all or nothing. Because of the design of the American trial process, the victim is pitted against the offender. If the offender is not sentenced with the most harsh penalty, the victim somehow loses. Tying the victim's "win" to the state's performance is already problematic, particularly because the state's role effectively ends once a conviction is secured. Once the assailant is imprisoned or executed, little is done to address the anger and grief experienced by the victim.

Complicating the issue is the addition of "undesirable" victims: victims that are poor, criminal, unattractive, those who do not exhibit the "appropriate" emotional response, or who are, in some way, alien to the notion of one who deserves the protection of the state. As we have seen, it has not always been in the state's interest to represent fully and accurately the views of those that are marginalized by the system. It is unclear whether the voices of these victims will be heard as well. If the story will not help to secure a conviction or particular punishment, and if the victim does not fit into the box created by the state, the prosecution may shy away from using such evidence at trial or the jury may discount the victim's story. The result is to extrinsically value certain victims over others and to further alienate those who cannot find a place in the current legal system.

\section{VII}

\section{CONCLUSION}

Given the failings of the current system to embrace a more universal and gender-equitable structure, it is evident that a massive overhaul of the criminal justice system is in order-particularly with respect to capital cases. Despite the Supreme Court's insistence that judges and juries consider the individual merits

148. Kent Roach, Four Models of the Criminal Process, 89 J. CRIM. L. \& CRIMINOLOGY 671, 711 (1999) (quoting Carol Smart).

149. Bandes, supra note 145 , at 393. 
of each capital case, these merits are considered according to very carefully delineated boundaries. Absent from consideration are the context of the crime committed and a true understanding of the humanity of the defendant or the victim. Pervasive in the system is an emphasis on retribution and revenge based on an all-or-nothing outcome. Those defendants who lose are silenced entirely out of the equation, and the system learns nothing from their experience. The result is to emphasize traditionally masculine conceptions of the world that exclude the voices of those who do not already fit into this perspective.

To create a truly equitable system would require a massive overhaul not only of the current law, but also of the political and social conceptions of those who make, execute, and encounter the law. Simply accommodating women's voices by inserting them into a male system is insufficient and cannot address the deep-seated inequities in the system. For example, acknowledging the impact of crime on the victim is a worthy enterprise, but using the statements in the context of sentencing distorts its purpose. Rather, we should consider how the state could help victims voice their experiences and recover from the crime, perhaps through state-sponsored counseling or a more meaningful interaction between the prosecutor and the victim's family. Likewise, the courts should reconsider the restriction of opponents of capital punishment on sentencing juries. We should entrust such grave matters as imposing a death sentence to juries that more accurately reflect the diverse voices in our society.

Additionally, it is important for feminist organizations to realize the connection between the death penalty and their own objectives. Once the punishment is seen as affecting more than just the few thousand who sit on death row, we can begin a more productive conversation. Ultimately, we can use the abolition of the death penalty as a means to re-invent the criminal justice system, to call into question the tenets upon which our criminal law is based, and to reinvigorate the system with a more universal perspective.

From a practical point of view, achieving true gender equity is nearly overwhelming. The task is not impossible, however. For example, feminist theory has already led to new ways of using the law, for example, leading to the creation of rape-shield laws, recognizing marital rape, and identifying sexual harassment. Such a task is equally important here in the context of capital punishment. Before that process can begin, however, we must move away from traditional methods of considering reform. It is important for legislators to seek broader input on legislation and for courts to reflect more thoroughly upon whose voices they are representing. Imposing death as punishment when we, as a society, are so far from the heart of the debate is simply too great a price to pay. 